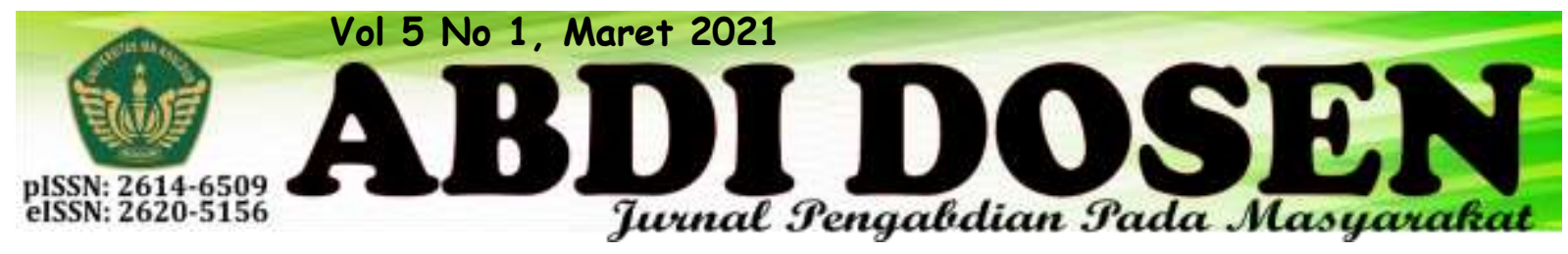

\title{
PENDAMPINGAN KADER POSYANDU LANSIA KOTA MALANG
}

\author{
Nur Lailatul Masruroh ${ }^{1}$, Titik Agustiyaningsih ${ }^{2}$, Anggraini Dwi Kurnia $^{3}$, Nur Melizza ${ }^{4}$, \\ Nabilah Arief ${ }^{5}$, Fransiska Prameisela ${ }^{6}$ \\ masruroh@umm.ac.id ${ }^{1}$ \\ Departemen Komunitas, Fakultas Ilmu Kesehatan, Universitas Muhammadiyah Malang ${ }^{1,2,3,4}$, Mahasiswa \\ Keperawatan, Fakultas Ilmu Kesehatan, Universitas Muhammadiyah Malang 5,6
}

\begin{abstract}
ABSTRAK
Dengan meningkatnya populasi lansia, maka diperlukan penilaian berkala untuk deteksi dini kesehatan lansia dengan penyediaan layanan kesehatan yang terjamin, berkualitas dan terlaksananya pelayanan pada lanjut usia melalui kelompok (posyandu) lanjut usia yang melibatkan semua lintas sektor terkait, swasta dan swadaya masyarakat. Posyandu Rw 09 Kelurahan Pandanwangi berdiri sejak Desember 2018, dengan permasalahan utama adalah rendahnya angka kunjungan lansia ke posyandu lansia dan kurangnya pemahaman lansia akan permasalahan kesehatannya (tingginya angka lansia penderita hipertensi $(54,20 \%)$, hiperkolesterol (34,20\%), serta keluhan lain adalah nyeri sendi $(20 \%)$ dan TB paru $(2,8 \%)$. Metode pelaksanaan yang dilakukan team pengabdian masyarakat adalah dengan memberikan penyuluhan kesehatan untuk meningkatkan pemahaman lansia dan keluarga tentang berbagai penyakit yang diderita serta bagaimana perawatannya termasuk pentingnya melakukan monitoring kesehatan berkala dengan melakukan kunjungan ke posyandu lansia secara rutin, dan juga dilakukan pelatihan kepada kader kesehatan tentang pemeriksaan tekanan darah dan demontrasi senam lansia. Dengan penyuluhan yang diberikan telah dapat meningkatkan pengetahuan lansia dan keluarga tentang penyakit dan pentingnya melakukan kunjungan ke posyandu lansia. Serta dengan kegiatan pendampingan kader posyandu lansia diharapkan dapat meningkatkan kualitas layanan yang diberikan kader kesehatan sehingga juga meningkatkan minat lansia untuk datang ke posyandu lansia.
\end{abstract}

\section{Kata Kunci : Kader Posyandu, Meningkatnya Populasi Lansia, Permasalahan Kesehatan}

\section{PENDAHULUAN}

Jumlah populasi lanjut usia semakin meningkat yang sekaligus menimbulkan berbagai permasalahan kesehatan baik secara fisik, biologis, psikologis maupun sosial ekonomi. Semakin lanjut usia seseorang kemampuan fisiknya akan semakin menurun, sehingga mengakibatkan gangguan dalam memenuhi kebutuhan hidup sehingga tingkat ketergantungan lansia pada orang lain meningkat
(Masruroh, N.L; Wardoyo, S.I., 2020). Salah satu bentuk perhatian terhadap kesehatan lansia adalah penilaian berkala untuk deteksi dini kesehatan lansia dengan penyediaan layanan kesehatan yang terjamin, berkualitas dan terlaksananya pelayanan pada lanjut usia melalui kelompok (posyandu) lanjut usia yang melibatkan semua lintas sektor terkait, swasta dan swadaya masyarakat (Sulaiman, 
S., Sutandra, L., Vera, Y., \& Anggriani, A., 2018; Kusumawardani, D., \& Andanawarih, P., 2018).

Posyandu Rw 09 Kelurahan Pandanwangi berdiri sejak Desember 2018. Layanan awal yang diberikan meliputi : pendataan lansia, pengukuran tinggi badan, pengukuran berat badan dan pengukuran lingkar perut. Pada bulan berikutnya macam layanan yang diberikan mulai berkembang dengan adanya senam lansia, pengukuran tanda-tanda vital serta pengukuran gula darah, kholesterol dan asam urat yang dikenakan biaya. Saat ini jumlah kader kesehatan yang terlibat sejumlah 7 orang yang merupakan warga setempat. Rw 09 mencakup 11 Rt yang jaraknya tidak begitu jauh dari posko posyandu, posko posyandu terletak di salah satu rumah warga yang bertujuan untuk mendekatkan jangkauan lansia agar lebih dekat mendatangi posyandu. Biaya yang digunakan untuk mendirikan posyandu merupakan swadaya

\section{METODE PELAKSANAAN}

Metode pelaksanaan yang dilakukan dalam kegiatan pengabdian masyarakat ini adalah dengan memberikan penyuluhan kesehatan untuk meningkatkan pemahaman lansia dan keluarga tentang berbagai penyakit yang diderita serta bagaimana perawatannya termasuk pentingnya melakukan monitoring kesehatan berkala dengan melakukan kunjungan ke posyandu lansia secara rutin, penyuluhan dilakukan dengan menggunakan media audio visual melalui LCD serta leaflet yang dibagiakan yang berisi informasi tentang berbagai makanan yang harus diwaspadai karena kandunagn kolesterol yang tinggi. Selain itu juga dilakukan pelatihan kepada kader kesehatan tentang bagaiamna cara melakukan pemeriksaan tekanan darah. Kegiatan penyuluhan diakhiri dengan dari masyarakat, setiap RT di anggarkan untuk membayar sebesar Rp.15.000 digunakan untuk modal awal (sewa meja, sewa alat dan konsumsi). Lansia yang berada di Rw 09 mencapai 600 lansia, akan tetapi yang mengikuti posyandu hanya 100 lansia saja (10\%). Lambat laun lansia yang datang keposyandu menurun tinggal 50-60 lansia saja (5-6 \%). Dengan permasalahan utama mitra adalah rendahnya angka kunjungan lansia ke posyandu lansia dan kurangnya pemahaman lansia akan permasalahan kesehatannya ( tingginya angka lansia penderita hipertensi $(54,20 \%)$, hiperkolesterol $(34,20 \%)$, serta keluhan lain adalah nyeri sendi (20\%) dan TB paru $(2,8 \%)$ untuk itu kader posyandu lansia memerlukan bantuan untuk mensosialisasikan keberadaan layanan Posyandu Lansia ke masyarakat serta edukasi tentang berbagai penyakit yang diderita lansia serta perawatannya kepada lansia dan juga keluarga.

demontrasi senam lansia yang diputarkan melalui video dan demonstrasi langsung dan penyerahan set alat untuk pemeriksaan kesehatan dan media promosi kesehatan.

Pemberian penyuluhan dengan menggunakan media audio visual kepada lansia dan kader kesehatan digunakan sebagai strategi dalam pengabdian masyarakat ini karena terbukti efektif untuk meningkatkan pemahaman peserta (Andayani et al, 2019) Sedangkan dengan metode demonstrasi merupakan metode pembelajaran yang juga terbukti efektif, karena peserta dapat melihat secara langsung penerapan materi tersebut dalam kehidupan sehari-hari (Huda, 2013).

Adapun evaluasi penyuluhan kesehatan dalam project pengabdian 
masyarakat ini dilakukan melalui tanya jawab langsung dengan para peserta.

\section{LUARAN DAN PEMBAHASAN}

Kegiatan pengabdian masyarakat ini dilakukan pada bulan Januari 2020 sesuai dengan jadwal posyandu lansia, bertempat di rumah salah satu warga RW 09 Kelurahan Pandanwangi Kota Malang. Kegiatan ini dihadiri oleh Tim Pelaksana Program pengabdian Masyarakat dari Departemen Keperawatan Komunitas Fakultas Ilmu Kesehatan Universitas

Muhammdiyah Malang, Mahasiswa Ners angkatan 20 yang sedang menjalani praktek stase departemen Keperawatan Komunitas, pihak puskesmas Pandanwangi, 8 orang kader kesehatan, serta 24 orang lansia yang didampingi oleh keluarganya. Kegiatan dimulai dari jam 09.00 pagi dan berakhir menjelang dhuhur.

Tabel 1. Karakteristik peserta lansia yang hadir

\begin{tabular}{llll}
\hline \multicolumn{1}{c}{ Karakteristik } & n & f (\%) & Rerata \\
\hline Usia lansia & 24 & & 65,25 \\
& & & \\
Jenis kelamin : Perempuan & 24 & $100 \%$ & \\
Hipertensi & 12 & $50 \%$ & \\
Hiperkolesterol & 8 & $30 \%$ & \\
Nyeri Sendi & 10 & $41 \%$ & \\
\hline
\end{tabular}

Dari hasil evaluasi secara sumatif menunjukkan bahwa secara keseluruhan kegiatan berjalan dengan baik dan lancar, Lansia dan keluarga tampak antusias mengikuti seluruh kegiatan penyuluhan dari awal hingga akhir serta dapat menjawab pertanyaan petugas dengan baik sebagai salah satu bentuk evaluasi terhadap tingkat pemahaman mereka akan materi yang telah disampaikan. Selain itu lansia dan keluarga juga dapat mendemontrasikan senam lansia, serta kader dan keluarga mampu melakukan pengukuran tekanan darah secara mandiri.
Kegiatan pengabdian masysrakat ini sejalan dengan hasil penelitian yang menyatakan bahwa pemberian informasi melalui penyuluhan kesehatan serta penadampingan kader merupakan strategi penting yang diterapkan sebagai solusi permasalahan mitra. Pengetahuan lansia akan manfaat posyandu lansia, serta kualitas pelayanan di posyandu lansia merupakan faktor penting yang mempengaruhi minat lansia untuk datang ke posyandu lansia (Saraisang, C. M., Kumaat, L. T., \& Katuuk, M. E., 2018; Putri, M., 2018). 


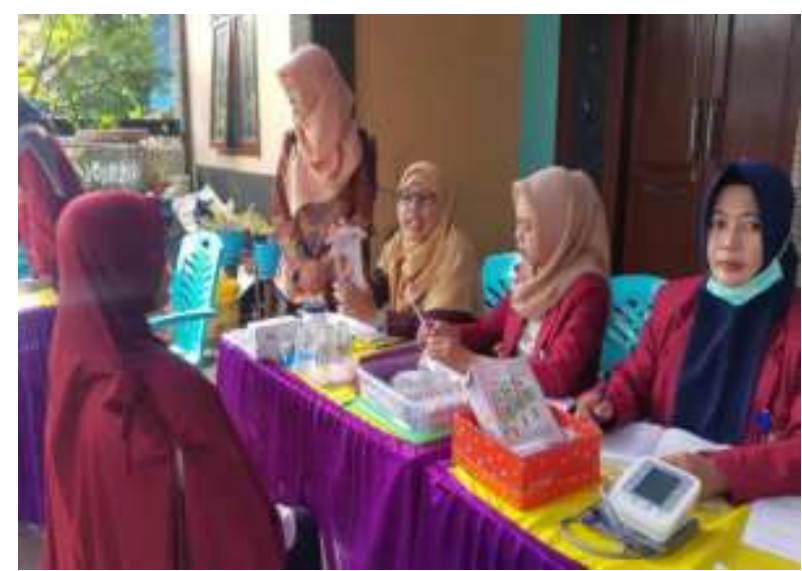

Gambar 1. Screening Kesehatan Lansia dan Edukasi

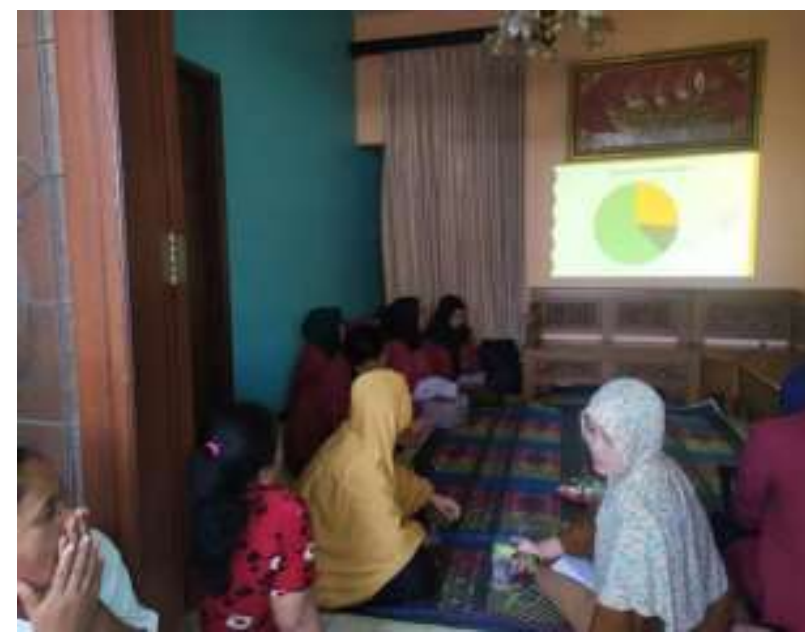

Gambar 2. Penyuluhan Kesehatan

\section{KESIMPULAN}

Kegiatan pengabdian masyarakat "Pendampingan kader Posyandu lansia kelurahan Pandanwangi Kota Malang" merupakan salah satu bentuk upaya untuk meningkatkan pengetahuan lansia dan keluarga tentang penyakitnya serta bagaimana perawatannya, salah satu tindakan perawatan yang penting dilakukan adalah dengan melakukan monitoring kesehatan secara berkala melalui memanfaatkan layanan Posyandu Lansia.

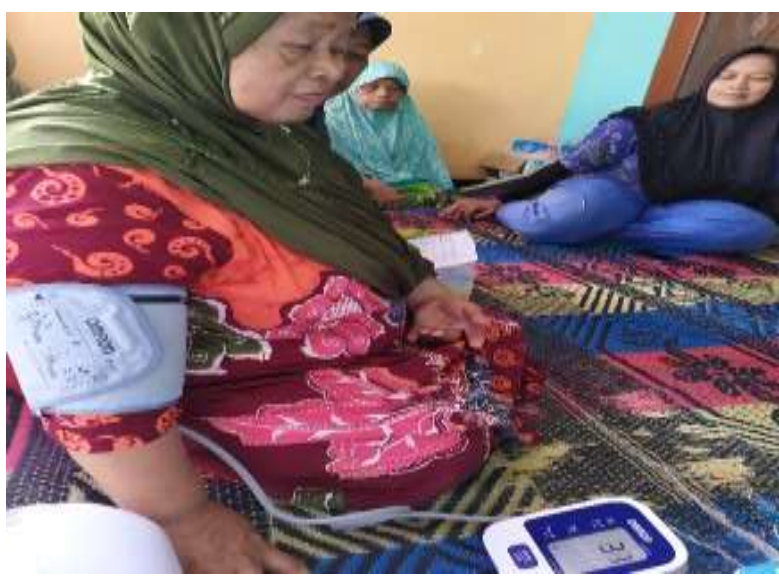

Gambar 3. Latihan Pengukuran Tekanan Darah

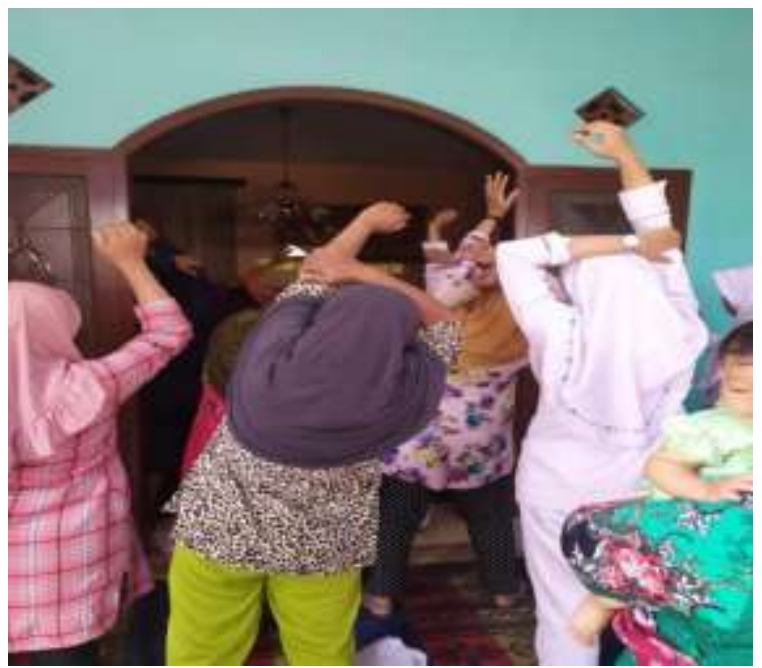

Gambar 4. Demonstrasi Senam lansia

Dengan penyuluhan yang diberikan telah dapat meningkatkan pengetahuan lansia dan keluarga tentang penyakit dan pentingnya melakukan kunjungan ke posyandu lansia. Serta dengan kegiatan pendampingan kader posyandu lansia diharapkan dapat meningkatkan kualitas layanan yang diberikan kader kesehatan sehingga juga meningkatkan minat lansia untuk datang ke posyandu lansia. 


\section{DAFTAR PUSTAKA}

Masruroh, N.L, Wardoyo, S. . (2020). The Quality of Health Care Service and The Elderly`s Attendance in Posyandu (Integrated Health Care Service Unit): a Correlational Study. Proceed, 20192021.

Putri, M. (2018). Determinant Factors to Liveliness of Elderly in participating Elderly Integrated Health Post. Jurnal Promkes, 6(2), 213-225.

Sulaiman, S., Sutandra, L., Vera, Y., \& Anggriani, A. (2018). Pendampingan Kader Posyandu Lansia di Suka Raya. Journal of Dedicators Community, 2(2), 116-122. https://doi.org/10.34001/jdc.v2i2.712

Saraisang, C. M., Kumaat, L. T., \& Katuuk, M. E. (2018). Hubungan Pelayanan Posyandu Lansia Dengan Tingkat Kepuasan Lansia Di Wilayah Kerja Puskesmas Ranomuut Kecamatan Paal Ii Kota Manado. Jurnal Keperawatan, 6(1).
Andayani, S. A., Khotimah, HAndayani, S. A., Khotimah, H., Desy, S., \& ... (2019). Efektivitas promosi kesehatan menggunakan media audiovisual terhadap keaktifan lansia ke Posyandu Lansia. Jurnal Keperawatan ..., 7. https://ejournal.unuja.ac.id/index.php/j kp/article/view/602

Kusumawardani, D., \& Andanawarih, P. (2018). Peran Posyandu Lansia Terhadap Kesehatan Lansia Di Perumahan Bina Griya Indah Kota Pekalongan. Siklus : Journal Research Midwifery Politeknik Tegal, 7(1), 273277.

https://doi.org/10.30591/siklus.v7i1.74 $\underline{8}$

Syakbania, D. N., \& Wahyuningsih, A. S. (2018). Higeia Journal of Public Health. Higeia Journal of Public Health Research and Development, 1(3), 84-94. 